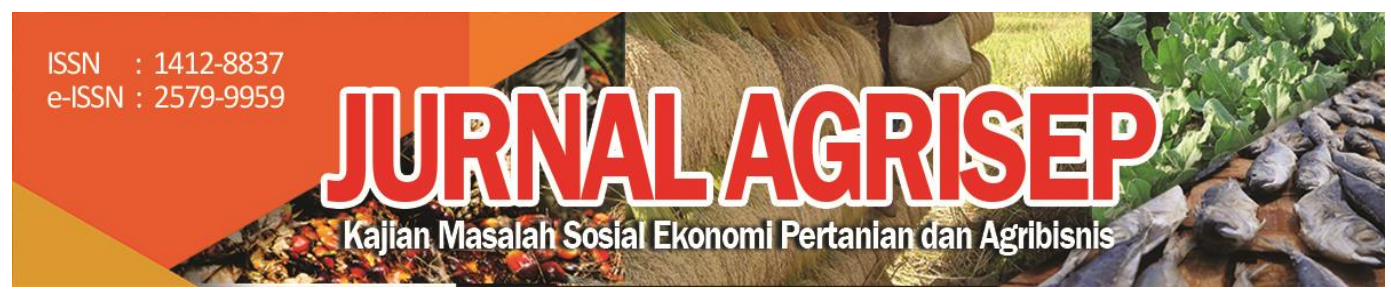

DOI: $10.31186 /$ jagrisep.19.2.417-432

\title{
SUSTAINABILITY ANALYSIS OF MILKFISH AQUABUSINESS MANAGEMENT ON SUMBAWA ISLAND: A BIOECOLOGY, TECHNOLOGY, AND ECONOMIC APPROACH
}

\author{
Evron Asrial1) $\square$, Aylee Christine Alamsyah Sheyoputri'2), Rusmin \\ Nuryadin ${ }^{3}$ \\ 1) Fakultas Perikanan Universitas 45 Mataram \\ 2)3) Fakultas Pertanian Universitas Bosowa Makassar \\ *Email: evronasrial81@gmail.com
}

\begin{abstract}
For more than three decades, the coastal communities have managed and utilized the coastal land of Sumbawa Island for milkfish (Chanos chanos) cultivation. They carry out the activities in ponds making the most of the tides and the coastal land topography. The choice of milkfish is due to the community fondness, euryhaline organisms, use of simple technology for aquaculturing, low cost, and high survival rate. The research objective is to find out the status of sustainability management of the dimensions of bioecology, technology, and economic as well to find out the sensitive attributes of each dimension. Sustainability is a mandate in the management of global and Indonesian fisheries. This research was conducted in three regencies (Sumbawa, Dompu, Bima) from June to October 2018. The data collection employed the method of dependent-survey and the techniques comprised sampling, dialogue, observation, and documentation. The data processing of the whole attributes employed various statistical and non-statistical equations. The sustainability analysis of the management dimensions made use of the technique of Rapid Appraisal (RAP) for milkfish aquabusiness (Rapmilkfish). The Rapmilkfish Analysis results that the sustainability status of the dimension of bioecology is 'Sustainable', technology is 'Quite Sustainable, economic is 'Less Sustainable', and the number of sensitive attribute is 12 attributes. This research conclude that application level of milkfish aquaculture technology is classified as environmentally friendly and positively correlated to the sustainability of natural resources. Therefore, the milkfish aquaculture activities can be continued without having to bring up the level of milkfish aquaculture technology in an effort to raise pond productivity.
\end{abstract}

Keywords: Aquaculture, Coastal, Milkfish, Rapmilkfish, Sustainability 


\begin{abstract}
ABSTRAK
Selama lebih dari tiga dekade, masyarakat pesisir telah mengelola dan memanfaatkan lahan pesisir Pulau Sumbawa untuk budidaya bandeng (Chanos chanos). Mereka memanfaatkan pasang surut dan topografi daratan pesisir untuk melakukan kegiatan di tambak. Bandeng dipilih karena: kegemaran masyarakat, organisme euryhaline, teknologi budidaya bandeng tergolong sederhana, biaya produksi rendah, dan sintasan tinggi. Tujuan penelitian untuk mengetahui status keberlanjutan pengelolaan dimensi bioekologi, teknologi, dan ekonomi serta mengetahui atribut-atribut sensitif dari masing-masing dimensi. Keberlanjutan merupakan amanat dalam pengelolaan perikanan dunia dan Indonesia. Penelitian ini dilakukan di tiga kabupaten (Sumbawa, Dompu, Bima) selama Juni - Oktober 2018. Penghimpunan data menerapkan metode survey dependen dengan teknik sampling, dialog, observasi, dan dokumentasi. Pengolahan data menerapkan berbagai persamaan statistik dan non statistik. Analisis keberlanjutan menggunakan teknik penilaian untuk akuabisnis bandeng (Rapmilkfish). Hasil Analisis Rapmilkfish menunjukkan status keberlanjutan dimensi bioekologi 'Berkelanjutan', dimensi teknologi 'Cukup Berkelanjutan', dimensi ekonomi 'Kurang Berkelanjutan', dan atribut sensitif sebanyak 12 atribut. Dapat disimpulkan bahwa tingkat penerapan teknologi budidaya bandeng tergolong ramah lingkungan dan berkorelasi positif dengan kelestarian sumber daya alam. Sehingga, kegiatan budidaya bandeng dapat dilanjutkan tanpa harus menaikkan taraf teknologi budidaya bandeng dalam upaya meningkatkan produktivitas tambak.
\end{abstract}

Kata kunci: Bandeng, Budidaya, Keberlajutan, Pesisir, Rapmilkfish.

\title{
INTRODUCTION
}

The stakeholders have long been utilizing the culture areas in the coastal areas of Nusa Tenggara Barat (NTB) as milkfish aquabusiness areas. The development of aquabusiness has great potentials to meet the consumption needs and inexpensive animal protein for the Indonesian people. Milkfish culture has comparative and competitive advantages. It is comparative because it does not apply factory feed so it does not produce waste and is environmentally friendly. It is competitive because the culture is of low-cost. The commodities cultured by fish farmers in ponds are milkfish (Chanos chanos Forskal 1925) and vaname shrimp. Coastal communities utilize their ponds for milkfish culture using aquabusiness system. The milkfish aquaculture business is growing rapidly and widely along the coastal areas of Sumbawa Island, especially in the regencies of Sumbawa, Dompu, and Bima.

Milkfish is a type of popular consumption fish in the Southeast Asian and region, and the only existing Chanidae species. Milkfish is a type of euryhaline fish, which can live in a fairly wide range of salinity (0-140 ppt). Hence, milkfish can live in fresh water (ponds/rice fields), brackish water (ponds), and salt water (coastal waters). According to Purnomowati, et al. (2007), milkfish return to the 
sea to breed as adults. The milkfish aquabusiness in the ponds is expected to be able to create business opportunities, reduce workforce unemployment, and increase the community income. The ultimate goal is improving welfare and reducing criminality, an impact of money supply increase.

The sustainability of aquabusiness and the choice of milkfish commodity by milkfish farmers is evaluated through bioecology, technology, and economic dimensions (bioecotechnomy). Bioecologically, the pond land lies in a tidal zone, a temperate type climate, an annual river type, and an alluvial type soil. From the technology perspective, milkfish culture relies on natural gifts such as tides, precipitation, sunshine, and soil fertility. From the economic aspect, it is facilitated because the consumers and their demands remain routine, increasing sharply during religious holidays. According to Muliawan et al. (2016), the problem of managing milkfish cultivation is the ecological dimension and the economic dimension which is 'less sustainable'.

A small portion of milkfish aquabusiness experiences problems based on bioecotechnomy approach. The milkfish aquabusiness problems in the study locations are the availability of seed milkfish (Indonesian = nener) suitable for cultivation, ponds construction (prone to flooding), and milkfish prices fluctuate. The issues arise due to inadequate pond embankment construction in consequence of the employment of simple technology, making use of conventional tools of hoes. High rainfall and rising tides results in floods and submerging ponds causing milkfish escaped into the sea. The absence of fish auctions, and the formation of cartels reduce the price of milkfish below the equilibrium point. All of these issues lead to loss or bankruptcy of milkfish aquabusiness.

This study is important because it aims to produce many standards and norms to assess the sustainability of milkfish aquabusiness management. Apart from that, to find out another important values related to the sustainability of the milkfish aquabusiness activities in NTB, especially on Sumbawa Island. Therefore, the community thoughts related to the local values and norms in the management of milkfish aquabusiness are needed. The aim is to find out and describe the problems and constraints of milkfish aquabusiness sustainability in the form of management attributes in multidimensional bioecotechnomy

\section{RESEARCH METHOD}

\section{Location And Period Of The Research}

This research is located on the coastal area of Sumbawa Island. Administratively, the location is spread in Saleh Bay (Tarano, Sumbawa Regency), Cempi Bay (Woja, Dompu Regency), and Bima Bay (Woha, Bima Regency) (Figure 1) and took place in the period of June 1 - October 31, 2018. The 
researchers visited the study site four times to collect data and information of the milkfish aquabusiness. Each visit to the study location to collect data on each dimension. The first visit was for site orientation, and the second to fourth visits each collected data on the bioecological dimension, the technological dimension, and the economic dimension. Another activity was an interview with the local milkfish farmers.

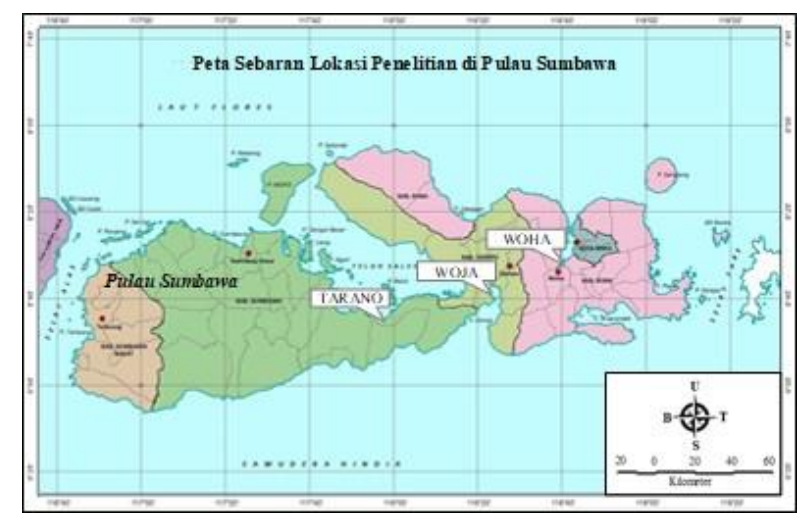

Figure 1.

Map Of The Distribution Of Research Locations

\section{Data Collection And Data Types}

This research applies descriptive dependent survey method that is indepth observation activities and data collection that depend on other parties. The goal is to obtain feasibly processed information and data, that is, right, good, trusted, sufficient, and representative. The data represents a problem, an event, or a phenomenon occurring in a limited area and time span.

The data, the main material in this research, are divided into secondary data (time series) and primary data (cross section). The time series data were sourced from the Department of Maritime Affairs and Fisheries (Sumbawa Regency, Dompu Regency, and Bima Regency). While the primary data were obtained from the interviews with milkfish farmers, measurements, and direct observations of the research objects. Primary data are in the Bioecological Dimension (river type, estuary distance to the pond, climate type), Technological Dimension (pond drainage, pond liming, pond fertilization, pond water disposal, pond cleaning), and Economic Dimension (all attributes). Meanwhile, data another attributes is secondary data group. The main equipment used were stationery, camera, and recording equipment, and data processing equipment (computer). Primary data from all attributes in the three dimensions were obtained by measuring, observing, having dialogue (individually, focus group discussion), and processing data. 
The respondent, as much as $10 \%$ of the total milkfish cultivators, was drawn randomly using the simple random sampling method to collect primary data. Meanwhile, secondary data were collected through documentation techniques consisting of published documents, reports, and annual data.

\section{Method Of The Analysis Of The Management Sustainability Status}

The evaluation of the fishery sustainability status employing Rapid Appraisal for Fisheries (Rapfish) is a rapid assessment technique for fisheries (Pitcher and Preikshot, 2001). It is the latest technique developed by the University of British Columbia Vancouver (Canada) in 1999. The status of the sustainability of milkfish aquabusiness management was analyzed using this method. This analysis aims to evaluate the multidimensional status of the sustainability of the management of milkfish aquabusiness in milkfish culture activities in ponds. Rapfish is based on the ordination technique of placing things in the order of attributes measured using Multi-Dimensional Scaling (MDS).

Rapfish dimensions regarding the sustainable attributes consist of ecology, economic, technology, social, and ethics, with fifty-one attributes (Pauly and Pitcher, 2000; Pitcher and Preikshot, 2001; Fauzi and Anna, 2002; Kavanagh and Pitcher, 2004). Hartono et al. (2005) developed those dimensions into ecology, technology, economic, social, and government (48 attributes). Having been employed throughout the world, the Rapfish method has been modified by many other researchers. A modification of Rapfish has been carried out by Asrial et al. (2015) and Asrial (2017) to develop a sustainable consumption management strategy for jellyfish, namely: Rapjellyfish. Rapfish is used to assess the sustainability of coastal waters management under the name of Rapcosmile (Asrial et al., 2017; Asrial, 2018).

\section{Rapid Appraisal For Milkfish Aquabusiness (Rapmilkfish)}

In this study, the method used for evaluating the sustainability of milkfish aquabusiness management is the Rapid Appraisal for Milkfish Aquabusiness (Rapmilkfish) with 38 attributes. The selection of all attributes referred to the importance of sustainable aquaculture in a propely and correctly fish farming method (CBIB) (DJPB KKP, 2015). Other references are Rapfish (Pitcher and Preikshot, 2001), Rapjellyfish (Asrial, 2017), Rapcosmile (Asrial, 2018), and Rapreefish (Asrial et al., 2018). So far there has been no study evaluating the sustainability of the management of milkfish aquaculture in a holistic manner. The application of Rapmilkfish in this analysis follows the procedure for Rapfish described by Alder et al. (2000) based on the ordination techniques (Figure 2). 


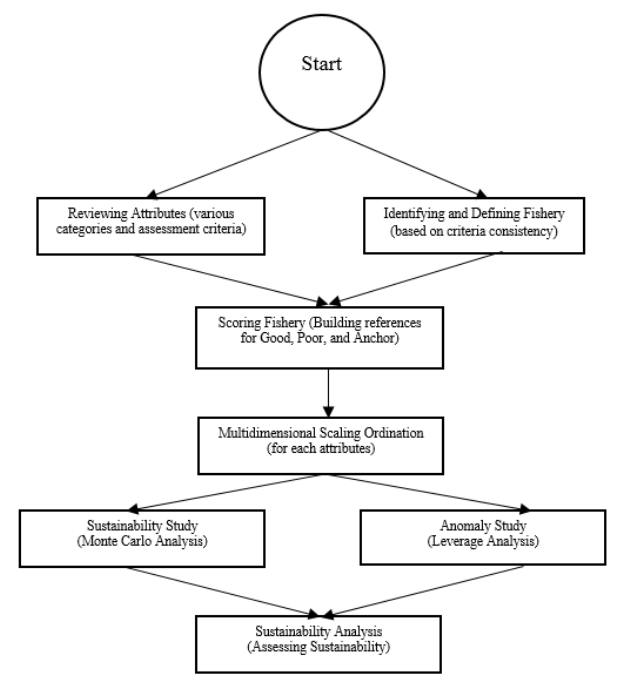

Figure 2.

The Process Element Of Rapmilkfish Application

The sustainability of milkfish aquabusiness management is assessed from three management dimensions, namely: bioecology, technology, and economic. The details are as follows:

1. Dimension of bioecology is approached from the perspectives of topography, hydrology, geology, climatology, and soil, totaling eight attributes.

2. Dimension of technology is viewed from the sciences of construction (civil engineering) and aquabusiness as well as regulations on how to fish farming properly and correctly (CBIB).

3. Dimension of economic is seen through the approaches of management economics, macroeconomics (development), and business economics (entrepreneurship).

In detail, all the sciences that form the basis of an approach for evaluating the sustainability status of milkfish aquabusiness management are outlined in questionnaire.

The Rapmilkfish analysis protocol starts by analyzing, identifying, and defining the management attributes to study (based on region, commodity, time, etc.). The next step is scoring based on the provisions formulated in Rapmilkfish. Then, MDS is conducted to determine the relative position (not absolute) of fisheries on the status of good and bad. After that, the Monte Carlo analysis is done to obtain sustainability status under uncertainty. Finally, the Leverage Analysis is done to predict deviations or anomalies of the management attributes analyzed and inventory the sensitive attribute groups.

MDS is a software for measuring similarity resulting in images/diagrams (Michael et al., 2014). It can be used to determine the position of objects, based on 
equality and inequality, using multivariate statistical analysis that can function as variable. MDS in Rapfish analysis was chosen because other multivariate analysis methods including factor analysis and Multi-Attribute Utility Theory (MAUT) lead to unstable results (Pitcher and Preikshot, 2001). Young and Hamer (1994) state that MDS is a data analysis technique that displays geometric images based on similarity or lack of similarity, on the basis of Euclidean distance. The ordination technique used in MDS is built upon the Euclidian distance in an $\mathrm{n}$ dimension space following the formula of:

$$
d=\sqrt{\left(\left|x_{1}-x_{2}\right|^{2}+\left|y_{1}-y_{2}\right|^{2}+\left|z_{1}-z_{2}\right|^{2}+\ldots\right)}
$$

After the ordination configuration of an object/point in MDS is obtained, it is then approximated by regressing the Euclidian distance ( $d i j)$ between point $\mathrm{i}$ to point $\mathrm{j}$ with the original point/origin $(d i j)$. The equation is $d_{i j}=a+b d_{i j}+e$ . The equation can be regressed employing the methods of (a) Least Square, (b) Squared Distance, dknown as ALSCAL, or (c) Maximum Likelihood. The ALSCAL algorithm, the most suitable for Rapfish, is easily obtained in almost every statistical software (SAS, SPSS) (Alder et al., 2000).

Measuring the goodness of fit - the distance between the point of estimation and the point of origin - is extremely important and significant. The goodness of fit in MDS measures the level of accuracy of the configuration of a point which can describe the original data reflected by the S-Stress value resulted from the RAP Analysis in Rapfish analysis. In Rapfish, the model can still be said to be good if the Stress value is less than 0.25 or less than $25.0 \%(\mathrm{~S}<25.0 \%$ ) (Fauzi and Anna, 2002). In other words, the constructed model can still be tolerated or accepted if the stress value is below $25.0 \%$.

The determination strength of all the attributes of each management dimension to the value of sustainability can be seen from the value of Squared Correlation (RSQ; $\mathrm{R}^{2}$ ) resulted from the RAP Analysis. The value of $\mathrm{R}^{2}=100 \%$ means Perfect, $R^{2}=>80-<100 \%$ (Very Strong), $R^{2}=>60-80 \%$ (Strong), $R^{2}=>40-$ $60 \%$ (Strong enough), $\mathrm{R}^{2}=>20-40 \%$ (Not Strong), and $\mathrm{R}^{2}=0-20 \%$ (Not Strong). By root squaring RSQ value, the Multiple $\mathrm{R}$ value reflecting the relation of all attributes to the management dimension will be secured.

The Rapmilkfish method, modified from Rapfish, consists of three dimensions (38 attributes), namely: bioecology (8 attributes), technology (16 attributes), and economic (14 attributes). Pada penelitian sejenis di Gresik (Jawa Timur), digunakan sebanyak 28 atribut untuk 5 dimensi pengelolaan (Muliawan et al., 2016). In this study, the types of analysis in Rapmilkfish include: (a) RAP Analysis to obtain the value of sustainability, the model deviation (stress), and determination (RSQ; ${ }^{2}$ ), and (b) Leverage Analysis to show the value of each attribute. The main objective is to determine the sustainability value of each management dimension, and the types of sensitive attributes that affect the sustainability status of management. 
The sustainability status of management is assessed by the comparative method using the standards of Susilo (2003). Sustainability status is divided into four strata, namely: Non-sustainable (0-25\%), Less Sustainable (> 25-50\%), Quite Sustainable (> 50-75\%), and Sustainable (> $75-100 \%)$.

The results of the sustainability assessment are stated in the index of the sustainability of the milkfish aquabusiness management activities in the pond. The sustainability index describes the sustainability status of the milkfish aquabusiness management activities studied based on the conditions occurring in 2018 and 2017. The sustainability index value of each dimension are determined by attaching value per dimension, data-based calculations available, or sourced from analysis results.

\section{RESULT AND DISCUSSION}

\section{Sustainability Analysis And Sensitivity Test}

\section{Dimension Of Bioecology}

Milkfish culture in ponds is classified as a land-based aquaculture group (Effendi, 2004), and therefore it is necessary to follow the technical criteria required for fish culture, namely: topography, soil type, water source, and land use (Susanto, 2002). Dimension of bioecology is important for it describes the natural physical condition of the study area. The attribute data of the dimension of bioecology are used to assess the management sustainability of that dimension (Table 1, Figure 3).

Table 1. Attributes And Data Of The Dimension Of Bioecology

\begin{tabular}{|c|c|c|c|c|c|}
\hline No. & Attributes & Poor & Good & Scale & Data \\
\hline 1 & Land Topography & 0 & 3 & $0=$ Hilly; 1 = Bumpy; 2 = Sloping; $3=$ Flat & Flat \\
\hline 2 & Land Slope & 0 & 3 & $0=>5 \% ; 1=>3-5 \% ; 2=1-3 \% ; 3=0-1 \%$ & $1 \%$ \\
\hline 3 & Soil type & 0 & 3 & $0=$ Sandy $; 1=$ Clay $; 2=$ Clay Sand $3=$ Sandy Clay & Sandy Clay \\
\hline 4 & River type & 0 & 3 & $\begin{array}{l}0=\text { Creek; } 1=\text { Intermittent } ; 2=\text { Ephemeral } 3= \\
\text { Perennial }\end{array}$ & Intermittent \\
\hline 5 & Estuary distance to the pond & 0 & 2 & $0=2.0 \mathrm{~km} ; 1=1.0-<2.0 \mathrm{~km} ; 2=\leq 1.0 \mathrm{~km}$ & $200-300 m$ \\
\hline 6 & $\begin{array}{l}\text { Climate type (Schmidt- } \\
\text { Ferguson) }\end{array}$ & 0 & 4 & $\begin{array}{l}0=\text { Wet } ; 1=\text { Rather Wet; } 2=\text { Medium; } 3= \\
\text { Rather Dry; } 4=\text { Dry }\end{array}$ & $\begin{array}{l}\mathrm{Q}=0.80 \\
\text { (Medium) }\end{array}$ \\
\hline 7 & Seed Source & 0 & 1 & $0=$ Nature $; 1=$ Seed Home & Seed Home \\
\hline 8 & Seed Size & 0 & 1 & $0=$ Fry $; 1=$ Fry and Fingerling $; 2=$ Fingerling & Mixed \\
\hline
\end{tabular}

Fishponds are generally located on the beach and river banks. The distance from the sluice of the fishpond area to the river mouth is between twenty and thirty meters. The river used to irrigate ponds is an intermittent type, that is, runny rivers in the rainy season. Based on Schmidt and Ferguon climate classification, the climate type of the study site is classified as "Climate D (Medium)" whose value of $Q$ is $80 \%$ 
The ecological condition of the fishpond area is utilized by coastal communities for milkfish culture. The milkfish seeds stocked are of fry and fingerling obtained from traders in Bima city. Almost all of the milkfish seeds are produced from hatcheries in Gondol (Bali). Only a small portion originated from each research location. Biologically, the seeds stocked are suitable to culture until they reach marketable size. The fishpond areas on the study site are built on the coastal area of flat land topography with the slope of zero to one percent, corresponding to the opinion of Hardjowigeno and Widiatmaka (2011). The soil is dominated by sandy clay. This soil type is suitable for fishponds, as required by Badrudin (2014).

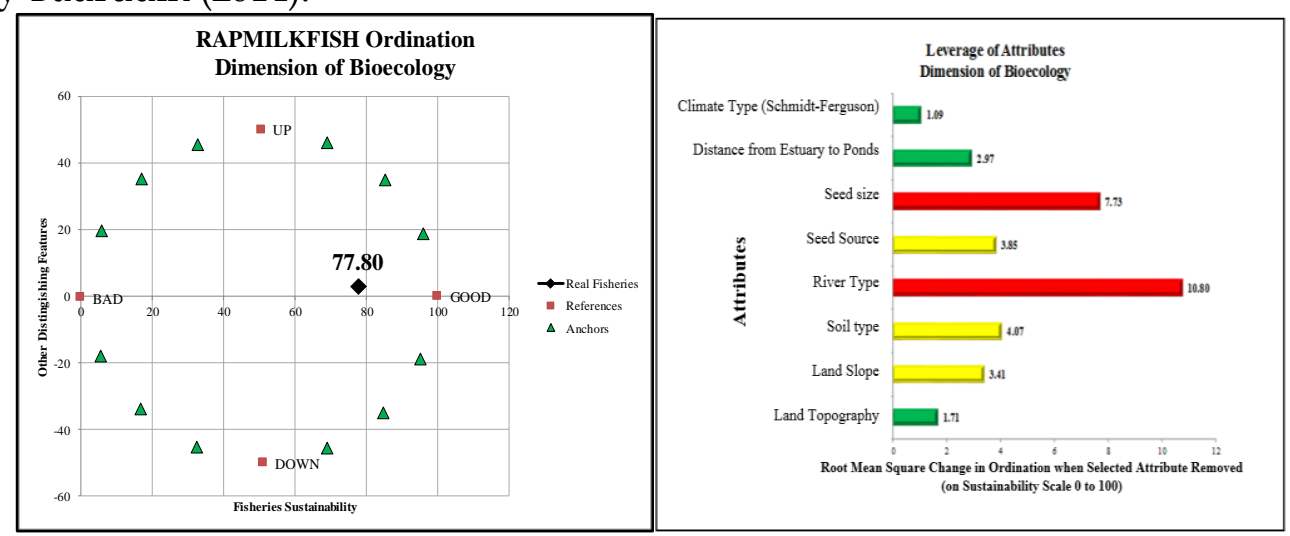

Figure 3.

Sustainability Analisys (Left) And Attribute Sensitivity Analysis (Right, Red Color) Of The Dimension Of Bioecology

The results show that the sustainability value reaches $77.80 \%$, which means that the dimension of bioecology is classified as "Sustainable (B)". In the meantime, there are two sensitive attributes $(25.00 \%)$, namely: (i) seed size and (ii) river type. This sustainability value is better than the value of the ecological dimension of the management of milkfish cultivation in Gresik (East Java) (Muliawan et al., 2016).

The coastal region which consists of coastal waters and coastal land is very thick with regional economic activities (rural) and sectoral economy (agriculture). In reality, farming sector activities in rural areas cannot always meet the needs of family or household life (Sheyoputri, 2016). Thus, the activities of the agricultural sector and rural areas in the corridors of the lowlands (coastal) to the highlands (hills) are always identical with poverty.

The fishpond areas on the coast of Sumbawa Island is very suitable for milkfish aquabusiness based on the criteria for the requirements of aquaculture land. This condition is in accordance with the criteria set by Susanto (2002), namely: climatology, topography, hydrology, geology, and land use. Pond land status is very appropriate (SS) adhering to the FAO stipulation (1976) in Hardjowigeno and Widiatmaka (2011), that is, such land does not have severe 
limitations for a certain sustainable use and does not significantly affect the productivity of the land. Thus, bioecologically, the milkfish farmers in the study site are eligible to utilize their ponds for milkfish aquabusiness.

\section{Dimension Of Technology}

Dimension of technology is needed to manage dimension of bioecology in order to provide benefits to human life and income. Humans (milkfish farmers) act as "operators" for the technology, and therefore humans are not included in the function of technology.

The milkfish culture activity in ponds is carried out with simple technology shown by 16 attributes of the dimension of technology (Table 2). The area of ponds ranging from 0.5-4.0 hectares/plot, the height of the embankment is 0.81.3 meters, equipped with a unified water quality management facility (in-let and out-let). In each pond there is a trough for milkfish to swim, and the yard is always submerged in water to foster the growth of klekap, a kind of algae, as the main feed for milkfish.

Table 2. Attributes And Data Of The Dimension Of Technology

\begin{tabular}{|c|c|c|c|c|c|}
\hline No & Attributes & Poor & Good & Scale/Score & Data \\
\hline 1 & Pond Construction & 0 & 3 & $0=$ Natural; 1 = Conventional $; 2=$ Modern; $3=$ Sophisticated & Hoe \\
\hline 2 & Sluice & 0 & 1 & $1=$ Shared; 1 = Separated & One Unit \\
\hline 3 & $\begin{array}{l}\text { Water Quality management } \\
\text { Facility }\end{array}$ & 0 & 2 & $0=$ None $; 1=$ Windmill $; 2=$ Water Pump & Water Pump \\
\hline 4 & Nursery Plot & 0 & 1 & $0=$ Not Any $; 1=$ Available & Not Any \\
\hline 5 & Embankment Height & 0 & 2 & $0=<$ HHWL $; 1=$ HHWL; $2=>$ HHWL & 1.0 meter \\
\hline 6 & Pond Drainage & 0 & 2 & $0=$ Not done; $1=$ Sometimes $; 2=$ Done & Once a year \\
\hline 7 & Pond Liming & 0 & 2 & $0=$ Not done; $1=$ Sometimes $; 2=$ Done & Every PB \\
\hline 8 & Pond Fertilization & 0 & 2 & $0=$ Not done $; 1=$ Done Once $; 2=$ Done Twice & Once/PB \\
\hline 9 & Pond Water Disposal & 0 & 2 & $0=$ Not done $; 1=$ During High Tide $; 2=$ At Low Tide & At Low Tide \\
\hline 10 & Pond Water Addition & 0 & 2 & $0=$ Not done $; 1=$ At Low Tide $2=$ At High Tide & At High Tide \\
\hline 11 & Pond Cleaning & 0 & 3 & $0=$ Not done $; 1=$ Irregularly $; 2=>$ every other day $; 3=$ every day & Irregularly \\
\hline 12 & Water Quality Monitoring & 0 & 3 & $0=$ Not done; $1=$ Irregularly $; 2=>$ every other day $; 3=$ everyday & Everyday \\
\hline 13 & Fish Health Monitoring & 0 & 3 & $0=$ Not done; 1 = Scatteredly $; 2=>$ Regularly $; 3=$ everyday & Not Done \\
\hline 14 & Fish Growth Monitoring & 0 & 2 & $0=$ Not done; $1=$ Irregularly $; 2=>$ Periodically & Not Done \\
\hline 15 & Harvest Decision & 0 & 3 & $\begin{array}{l}0=\text { Flood Disaster; } 1=\text { Stagnant Growth } ; 2=\text { High Demand } / \text { Price; } \\
3=\text { Harvest Size }\end{array}$ & $\begin{array}{l}\text { Consumer } \\
\text { Demand }\end{array}$ \\
\hline 16 & Harvest System & 0 & 2 & $0=$ Selectively $; 1=$ Selectively and Completely $; 2=$ Completely & $\begin{array}{l}\text { Selectively \& } \\
\text { Completely }\end{array}$ \\
\hline
\end{tabular}

Milkfish seeds are raised in pond construction (embankments, sluice) made using human power and hoes. Pond embankment height is lower than the highest high water level (HHWL). Hence, the pond floods every rainy season. The construction of embankments and sluice is not waterproof (leaking), which cause the entry of predatory fish into the ponds. The result is predation that causes a high mortality (low survival rate).

Throughout the preparation stage of the culture, farmers drain the ponds then dry the soil (once per year). Towards the dispersal of the fry, pond liming and fertilization are carried out at the beginning of the culturing period. The end of the preparation period is the addition of pond water to cover the surface of the ground. Liming aims to increase the soil $\mathrm{pH}$, thereby freeing $\mathrm{N}$ and $\mathrm{P}$ from 
$\mathrm{Al}$ and Fe windings in the soil (Hardjowigeno (2002). Such condition will inhibit the production of toxic gases and increase soil fertility because $\mathrm{P}$ is free from the bonds.

During the period of maintaining the seeds to the harvest, cleaning pond debris floating on the surface is carried out irregularly. Other activities are disposing pond water when the tide is low and increasing the pond water level when the tide is rising. In connection with the milkfish condition, the milkfish farmers monitor water quality as well as the milkfish health and growth. Through the results of the monitoring, the farmers decide on a harvest schedule plan after obtaining a request from the consumer (buyer). In general, all milkfish farmers harvest selectively and/or completely due to the demand. All of these activities are in accordance with the protocol of culturing fish properly and correctly.

The results of the activities in the dimension of technology are used for sustainability testing and sensitivity analysis of management attributes (Figure 4). The sustainability of the management worth was $55.96 \%$ or the status was "Quite Sustainable (CB)". This sustainability value is better than the value of the dimension of technology of the management of milkfish cultivation in Gresik (East Java) (Muliawan et al., 2016). Whereas the sensitivity analysis produced 6 (six) sensitive attributes (37.50\%). The most important roles in the formation of sustainability score so that they are low are the attributes of (i) pond water disposal and (ii) pond drainage.

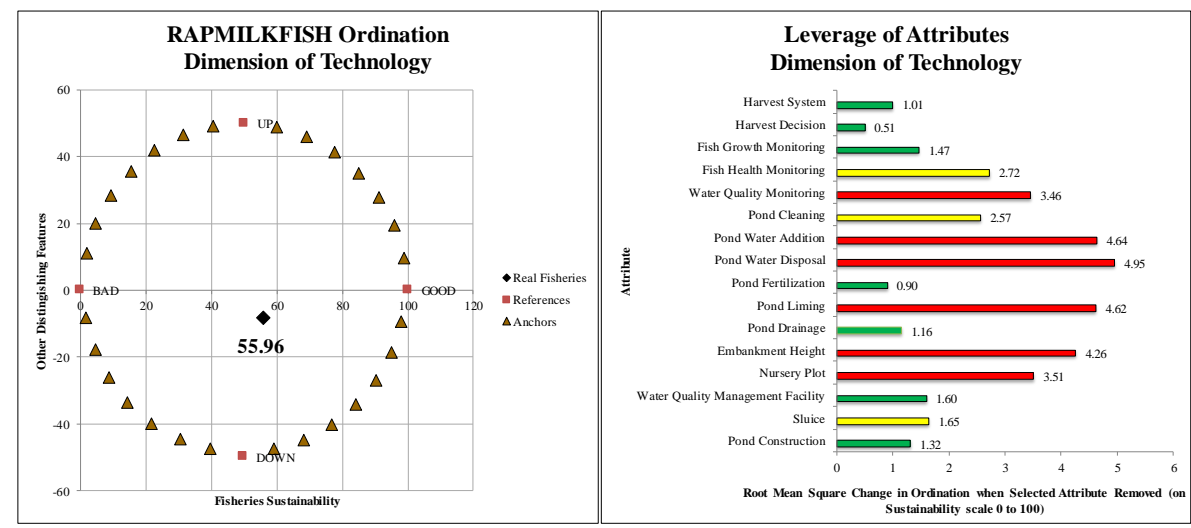

Figure 4.

Sustainability Analisys (Left) And Attribute Sensitivity Analysis (Right, Red Color) Of The Dimension Of Technology

The choice of fish culture (milkfish) and coastal land (ponds), the input factors of the production processed with simple technology by the milkfish farmers, is the right decision. The function formula is: $f\{V P\}=\{T a, B, T e, P\}$ where $V P=$ Production Volume $(\mathrm{Kg}), T a=$ Pond (hectare), $B=$ Seed (individual), 
$T e=$ Technology, namely: facilities/equipment in ponds (units), and $P=$ Milkfish Farmers (people). Meanwhile, the statistical model is:

$$
V P=a+b 1 T a+b 2 B+b 3 T e+b 4 P+e
$$

The choice of having milkfish, utilizing ponds, and employing simple technology is due to the limitations in: (a) the quantity and quality of farm facilities and infrastructure, and (b) capital and other technical capabilities. This condition is in line with Romadon and Subekti (2011), who stated that milkfish culture technique is quite simple to trigger and spur growth rates and accelerate the culture period. In fact, with this simple technology choice the milkfish farmers have been able to utilize ponds as containers for culturing milkfish. In other words, the farmers manage to avoid harvest failure.

\section{Dimension Of Economic}

The dimension of economic is used as an indicator for the level of welfare of milkfish farmers, seen from the perspective of their annual income. The same thing is applied to coastal communities connected as a multiplier effect of milkfish aquabusiness. The milkfish aquabusiness in a pond is carried out on self-owned land using capital sourced from family funds. The milkfish aquabusiness is a small-scale business that was carried out individually from the start.

Cultured milkfish have a fixed and guaranteed type of consumers and markets. The main consumers of milkfish aquaculture are collector traders and price tends to increase. Milkfish market status is a real one and the target market is consumers in the district area. The market system is oligopsony, which does not benefit the farmers (producers) because the pricing policy rests with the buyers (consumers). If the farmers retail the milkfish, they do it at the public market at the scale of traditional one (Table 3). This is done because of the compulsion when the milkfish farmers are in need for money.

Table 3. Attributes And Data Of The Dimension Of Economic

\begin{tabular}{|c|c|c|c|c|c|}
\hline No. & Attributes & Poor & Good & Scale/Score & Data \\
\hline 1 & Pond Ownership & 0 & 3 & $0=$ Rented $; 1=$ Mortgaged $; 2=$ Joint Operation; $3=$ Owned & Owned \\
\hline 2 & Capital Source & 0 & 3 & $0=$ Borrowed $; 1=$ Family $; 2=$ Combined $3=$ Individual & Family \\
\hline 3 & Business Scale/Class & 0 & 3 & $0=$ Micro $; 1=$ Small $; 2=$ Medium $; 3=\mathrm{Big}$ & $\begin{array}{c}\text { Small } \\
\text { Enterprise }\end{array}$ \\
\hline 4 & Business License & 0 & 4 & $\begin{array}{l}0=\text { No Lisence } ; 1=\text { Individual } ; 2=\text { Cooperative } ; 3= \\
\text { Comanditary } ; 4=\text { Company }\end{array}$ & Individual \\
\hline 5 & Consumer Type & 0 & 4 & $\begin{array}{l}0=\text { Household; } 1=\text { Peddler; } 2=\text { Collector Trader; } 3= \\
\text { Intercellular Trader; } 4=\text { Factory } / \text { Exporter }\end{array}$ & $\begin{array}{l}\text { Collector } \\
\text { Trader }\end{array}$ \\
\hline 6 & Price Trend & 0 & 2 & $0=$ Decreasing $; 1=$ Stable $; 2=$ Increasing & Increasing \\
\hline 7 & Market Status & 0 & 1 & $0=$ Virtual Market $; 1=$ Real Market & Real Market \\
\hline 8 & Market Target & 0 & 3 & $0=$ Local $; 1=$ Regency $; 3=$ Province $; 3=$ Export & Regency \\
\hline 9 & Market System & 0 & 2 & $0=$ Oligopsony $; 2=$ Auction; $3=$ Oligopoly & Oligopsony \\
\hline 10 & Market Type & 0 & 2 & $0=$ Public Market; 1 = Animal Market; 2 = Fish Market & $\begin{array}{l}\text { Public } \\
\text { Market }\end{array}$ \\
\hline 11 & Market Scale & 0 & 3 & $0=$ Traditional $; 1=$ Modern $; 2=$ Supermarket $3=$ Hygienic & $\begin{array}{c}\text { Traditional } \\
\text { Market }\end{array}$ \\
\hline 12 & R/C Ratio & 0 & 2 & $0=<1.0 ; 1=1.0 ; 2=>1.0$ & 6,17 \\
\hline 13 & $\begin{array}{l}\text { Fish Farmers' } \\
\text { Income }\end{array}$ & 0 & 2 & $\begin{array}{l}0=<\text { Regional Minimum Wage (UMR); } 1=\text { UMR; } 2= \\
>\text { UMR }\end{array}$ & $\begin{array}{c}\text { IDR } \\
4,844,761.00\end{array}$ \\
\hline 14 & Profit Transfer & 0 & 2 & $0=$ Out $; 1=$ Balanced In & In Regency \\
\hline
\end{tabular}

428 | Evron Asrial et al; Sustainability of Milkfish Aquabusiness... 
Milkfish aquabusiness for milkfish farmers provides positive benefits for family finance. The milkfish culture business is very feasible where the average $R / C$ Ratio $=6.17$ which means profitable because the $R / C$ Ratio $>1.0$. The average income earned was IDR 4,844,761 per month, exceeding the minimum regional wage (MRW) of NTB Province (IDR 2,012,610 per month). The benefits obtained by the milkfish farmers are enjoyed/spent by the coastal communities to the scope of the regency.

Sustainability analysis and sensitivity test of the dimension of economic (Figure 5) yielded $47.48 \%$ and four sensitive attributes. The score of milkfish aquaculture management sustainability means "Less Sustainable (LS)." This sustainability value is similar with the value of the economic dimension of the management of milkfish cultivation in Gresik (East Java) (Muliawan et al., 2016). The sensitive attributes having the greatest influence on the sustainability valueare (i) target markets and (ii) price trends.

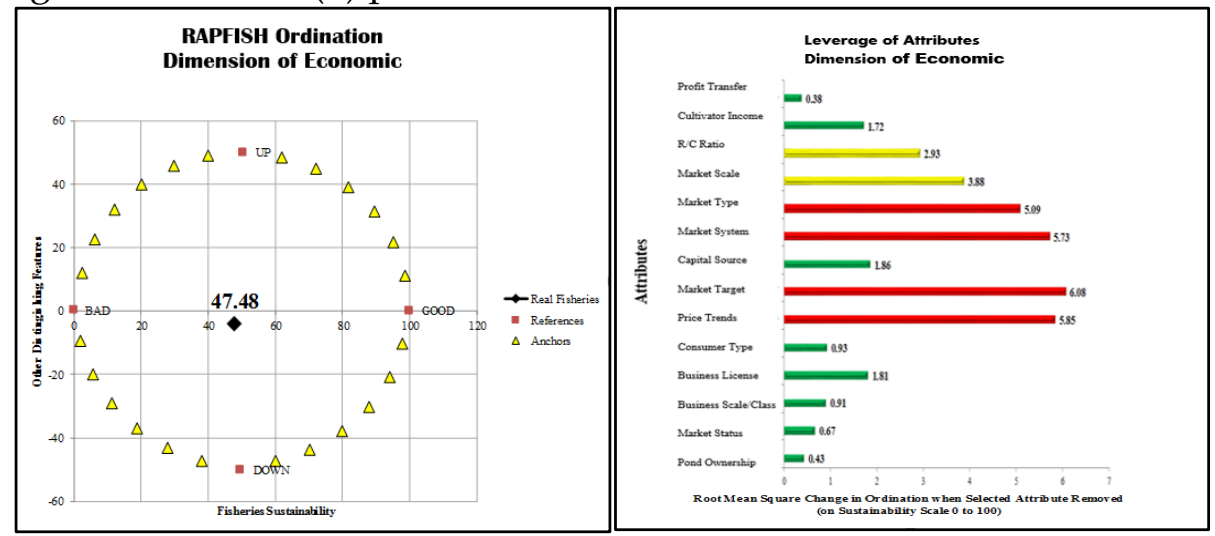

Figure 5.

Sustainability Analysis (Left) And Attribute Sensitivity Analysis (Right, Red Color) Of The Dimension Of Economic

\section{SENSITIVE ATTRIBUTES}

Sensitive attributes are attributes that affect the value of management sustainability. The greater the sensitive attribute value, the smaller the sustainability value, and vice versa. The greater the number of sensitive attributes, the greater the costs that must be spent on interventions to make improvements. Referring to the results of the Leverage Analysis, it is known 12 sensitive attributes. They are found in the Bioecological Dimension ( 2 attributes) (Figure 3), the Technology Dimension (6 attributes) (Figure 4), and the Economic Dimension (4 attributes) (Figure 5). Some of the improtant sensitive attributes that are very influential include: (a) Bioecological Dimensions (seed size, river type), (b) Technology Dimensions (pond water disposal, pond water addition), and (c) Economic Dimensions (market system, market type). 
The size of milkfish (nener) seeds greatly affects their adaptability, resistance to disease, ability to avoid predators, and ability to compete with competitors. All individual seed abilities are aimed at avoiding death and increasing survival. The greater the size of the nener, the better the ability and endurance of the nener. The consequence is that the milkfish farmers spend more and more because the price of nener is getting higher. In the study location, all nener comes from the catch of fishermen in coastal waters which incidentally is not uniform in size and can be mixed with predatory fish seeds. It is best to get nener from the hatchery.

The best river type for aquaculture is the permanent type, which means that water is available throughout the year with the same flow during the rainy and dry seasons. The rivers in the study locations are generally periodic river types (more watery during the rainy season, very little water during the dry season) and episodic river types (watering a lot during the rainy season, less watering during the dry season). So that the planting season only lasts 1-2 times per year.

Cultivation is the management of water quality which is manifested in the form of replacing pond water (inserting and disposing). The goal is to get sufficient and decent pond water for milkfish. The activity of replacing pond water at the research location is carried out naturally by relying on water gates and tides sea water. In addition, milkfish farmers do not have a reservoir (Indonesian: tandon) to accommodate water mixed with mud. Thus, the results obtained are not optimal for improving pond water quality.

Fish cultivators sell badeng to traditional markets at the district level, which have a tendency of increasing prices. The reality is that the market type and market system are not in favor of the seller. The market system is oliposony, namely a market with few buyers (consumers) and many sellers (producers). Thus, the price decision rests with the buyer (price maker) and the seller as the price taker. The oligopsony market always disadvantages the seller (producer) because the price is always determined to be below the equilibrium point.

\section{CONCLUSION AND RECOMMENDATION}

\section{CONCLUSION}

1. The level of application of milkfish aquaculture technology is classified as environmentally friendly and positively correlated to the sustainability of natural resources.

2. Rapmilkfish analysis technique has good and dependable performance and capacity, as well as reliable in evaluating the sustainability status of milkfish aquabusiness management anywhere.

430 | Evron Asrial et al; Sustainability of Milkfish Aquabusiness... 
3. The low sustainability value of the technology dimension (55.96\%) and the economic dimension (47.48\%) shows the weakness of milkfish cultivators in overcoming external factors.

\section{RECOMMENDATION}

1. Extensification of milkfish cultivation activities by reusing abandoned pond land, and intensifying milkfish cultivation technology.

2. Modify and develop the Rapmilkfish technique continuously to minimize errors and maximize the management sustainability value.

3. As an initial step to improve the sustainability of the milkfish aquabusiness management, the parties need to improvise six sensitive attributes, namely seed size, river type, pond water discharge, additional pond water, market system, and market type.

\section{REFERENCES}

Alder, J., T.J. Pitcher, D. Preikshot, K. Kaschner, and B. Ferriss. 2000. How good is good? Rapid appraisal technique for evaluation of the sustainability status of the fisheries of the North Atlantic Sea around us with methodology review. Fisheries Centre, University of British Columbia. Vancouver, Canada. $50 \mathrm{p}$.

Asrial, E. 2017. Perikanan ubur-ubur konsumsi di Teluk Saleh: Pendekatan Multidimensi Pengelolaan Perikanan Berkelanjutan. Mitra Usaha. Bogor

Asrial, E. 2018. Pengelolaan sumber daya perairan pesisir: Metode penilaian keberlanjutan pengelolaan. Mitra Usaha. Bogor

Asrial, E., A. Prajitno, E. Susilo, and G. Bintoro. 2015. Rapjellyfish method to evaluate the sustainability status of edible jellyfish resources management in the Saleh Bay, Indonesia. IJRSR 6(7): 5190-5198

Asrial, E., Hamid, A. Rahmawati, L.A.T.T.W.S. Kalih, and R. Nuryadin. 2017. Measuring sustainability performance of coastal waters resources management (Case Study: Nusa Tenggara Barat Province, Indonesia). JBES 11(6): 19-32

Asrial, E., Hamid, A. Harris, L.A.T.T.W.S. Kalih, N.M. Satyawan, R. Nuryadin, and I. Soraya. 2018. Sustainable management strategy for grouper and snapper fisheries in Saleh Bay based Repreefish. [Indonesian] Mataram: Faculty of Fishery, Univesity of 45 Mataram. $105+\mathrm{v}$ p.

Badrudin (ed.). 2014. Budidaya ikan bandeng (Chanos chanos) pada tambak ramah lingkungan. WWF Indonesia. Jakarta. $37 \mathrm{p}$.

DJPB KKP. 2015. Peraturan Direktur Jenderal Perikanan Budidaya Nomor 65/Per-Djpb/2015 Tentang Petunjuk Pelaksanaan Sertifikasi Cara Budidaya Ikan Yang Baik. Direktorat Jenderal Perikanan Budidaya 
Kementerian Kelautan dan Perikanan. Jakarta

Effendi, I. 2004. Pengantar akuakultur. Penebar Swadaya. Jakarta

Fauzi, A. dan S. Anna. 2002. Evaluasi status keberlanjutan pembangunan perikanan: Aplikasi pendekatan Rapfish (Studi kasus perairan pesisir DKI Jakarta). Jurnal Pesisir dan Lautan 4(3): 7-15

Hardjowigeno, S., dan Widiatmaka. 2011. Evaluasi lahan dan perencanaan tataguna lahan. Cetakan II. UGM Press. Yogyakarta

Hardjowigeno, S. 2002. Ilmu tanah. Akademika Pressindo. Jakarta

Hartono, Tj.T., T. Kodiran, M.A. Iqbal, dan S. Koeshendrajana. 2005. Pembangunan teknik rapid appraisal for fisheries (RAPFISH) untuk mempengaruhi indikator performans penangkapan ikan berkelanjutan di Indonesia. Jurnal Ekonomi Perikanan VI(1): 65-76

Hout, M.C., M.H. Papesh, and S.D. Goldinger. 2014. Multidimensional scaling. Wiley Interdisciplinary Reviews: Cognitive Science 4(1), 93-103

Kavanagh, P. and T.J. Pitcher. 2004. Implementing Microsoft Excel Software for Rapfish: A Technique for the Rapid Appraisal of Fisheries Status. The Fisheries Center, University of British Columbia, Vancouver, B.C. Fisheries Centre Research Reports 12(2): 1-75

Muliawan, I., A. Zamroni, and F.N. Priyatna. 2016. Sustainbility study of milkfish farming management in Gresik. J. Kebijakan Sosek KP 6(1): 25-35

Pitcher, T.J. and D. Preikshot. 2001. RAPFISH: A rapid appraisal technique to evaluate the sustainability status of fisheries. Fisheries Research 49: 255270

Pauly, D. and T.J. Pitcher. 2000. Assessment and mitigation of fisheries impacts on marine ecosystems: A multidisciplinary approach for basin-scale inference, applied to the North Atlantic. in: Pauly D and TJ Pitcher (eds.). Methods for evaluating the Impact of Fisheries on North Atlantic Ecosystems. Fisheries Research Center Reports 8(2): 1-12

Purnomowati, I., D. Hidayati, dan C. Saparinto. 2007. Ragam Olahan Bandeng. Kanisius. Yogyakarta

Romadon, A. dan E. Subekti. 2011. Teknik budidaya ikan bandeng di Kabupaten Demak. Mediagro 7(2): 19 - 24

Sheyoputri, A.C.A. 2016. Mengenal dan Memahami Kemiskinan. CMB Press. Jakarta Susanto, R. 2002. Penerapan Pertanian Organik. Kanisius. Yogyakarta

Susilo, S.B. 2003. Keberlanjutan pembangunan pulau-pulau kecil: Studi kasus di Pulau Panggang dan Pulau Pari, Kecamatan Kepulauan Seribu, Jakarta. Disertasi. Sekolah Pascasarjana IPB. Bogor

Young, F.W. and R.M. Hamer. 1994. Theory and applications of multidimensional scaling. NJ: Erlbaum. Hillsdale.

432 | Evron Asrial et al; Sustainability of Milkfish Aquabusiness... 